\title{
STUDIES ON CHEMOTHERAPY OF PARASITIC HELMINTHS (VIII). EFFECTS OF SOME POSSIBLE NEUROTRANSMITTERS ON THE MOTILITY OF ANGIOSTRONGYLUS CANTONENSIS
}

\author{
Mamoru TERADA, Akira I. ISHII, Hideto KINO and Motohito SANO \\ Department of Parasitology. Hamamatsu University School of \\ Medicine. Hamamatsu 431-31, Japan
}

Accepted March 25, 1982

\begin{abstract}
Effects of some possible neurotransmitters such as GABA, adrenergic drugs, and 5-HT and their antagonists on the motility of Angiostrongy/us cantonensis were studied. Paralysis was caused by GABA. avermectin Bla (Av-Bia), piperazine and $\alpha$-adrenergic agonists such as adrenaline, noradrenaline, phenylephrine, clonidine and methoxamine, but not by $\beta$-adrenergic agonists such as isoproterenol. The paralysis by GABA or Av-Bia was antagonized by GABA antagonists such as picrotoxin and/or bicuculline with cholinergic agents such as $N$-methylcytisine ( $N-M C$ ) or eserine. The paralysis elicited by $\alpha$-adrenergic agonists was antagonized by $\alpha$-adrenergic antagonists such as phentolamine and dibenamine, but not by $\beta$-adrenergic antagonists such as propranolol. 5 -HT affected the motility of $A$. cantonensis paralytically or spastically. The paralysis induced by 5 -HT was antagonized by $\alpha$-adrenergic antagonists such as phentolamine and dibenamine, while the contraction induced by this compound was further stimulated by N-MC, but antagonized by strychnine. Other agents such as glutamine. glycine, aspartic acid, taurine, and substance $P$ showed little effect on the motility of $A$. cantonensis. From these findings on the neuropharmacological properties of $A$. cantonensis, it is suggested that this worm is useful as an excellent nematodal model for the investigation of anthelminthics. In addition, this worm mav also useful as one of screening models of drugs affecting the central nervous system in mammals.
\end{abstract}

Basical neuropharmacological studies on parasitic nematodes for the investigation of anthelminthics have been exclusively carried out on only one species. Ascaris suum (1-5). Recently, we have selected another species, Angiostrongyius cantonensis, as an excellent model of nematodes in our comparative and systematic studies on chemotherapy of parasitic helminths (6). In the previous paper, we reported effects of various cholinergic drugs on the motility of $A$. cantonensis and suggested that the excitatory cholinergic mecha- nism in this worm is nicotinic in nature (7). Though this mechanism in A. cantonensis was suggested to be basically similar to that reported in A. suum (1-5). A. cantonensis seemed to be remarkably superior to $A$. sunm regarding the sensitivity to various drugs.

In the present study, we have examined some neuropharmacological agents which are suggested to be neurotransmitters in the nervous system of both vertebrate and invertebrate animals (8.9). 


\section{MATERIALS AND METHODS}

Collecting the worms. Angiostrongylus cantonensis, and experiments on drug effects on the motility of this worm by the isotonic transducer method were as described in previous papers $(6,7,10)$.

The following drugs were used: eserine salicylate, $\gamma$-aminobutyric acid (GABA), propranolol bicuculline, taurine, substance $P$ [Sigma], phenylephrine hydrochloride, papaverine hydrochloride, piperazine dihydrochloride, glycine, sodium glutamate, aspartic acid [Wako], adrenaline [Daichi], strychnine sulfate, dibenamine hydrochloride [Nakarai], serotonin creatinine sulfate (5-hydroxytryptamine, 5-HT), picrotoxin hydrochloride [Tokyokasei], avermectin Bıa (Av-Bia)
[Merck], phentolamine [Takeda], noradrenaline [Sankyo], isoproterenol hydrochloride [Nikenkagaku], methoxamine hydrochloride [Nihonshinyaku], clonidine hydrochloride [Tanabe], pyrantel tartrate [Pfeizer], and $\mathrm{N}$ methylcytisine (N-MC), an alkaloid from Sophora flavescens. was kindly offered from Dr. T. Noro (Shizuoka College of Pharmacy).

\section{RESULTS}

Each figure shows the representative of 3 to 5 similar tracings.

Effects of GABA, Av-Bia and piperazine on the motility of $A$. cantonensis: Paralysis was caused by GABA $\left(10^{-5}-10^{-4} \mathrm{M}\right)$. AvBia $\left(3.6 \times 10^{-5} \mathrm{M}\right)$ and piperazine $\left(10^{-5}\right.$ $10^{-4} \mathrm{M}$ ) as shown in Figs. $1-3$, respectively.

Remarkably paralyzed preparations with
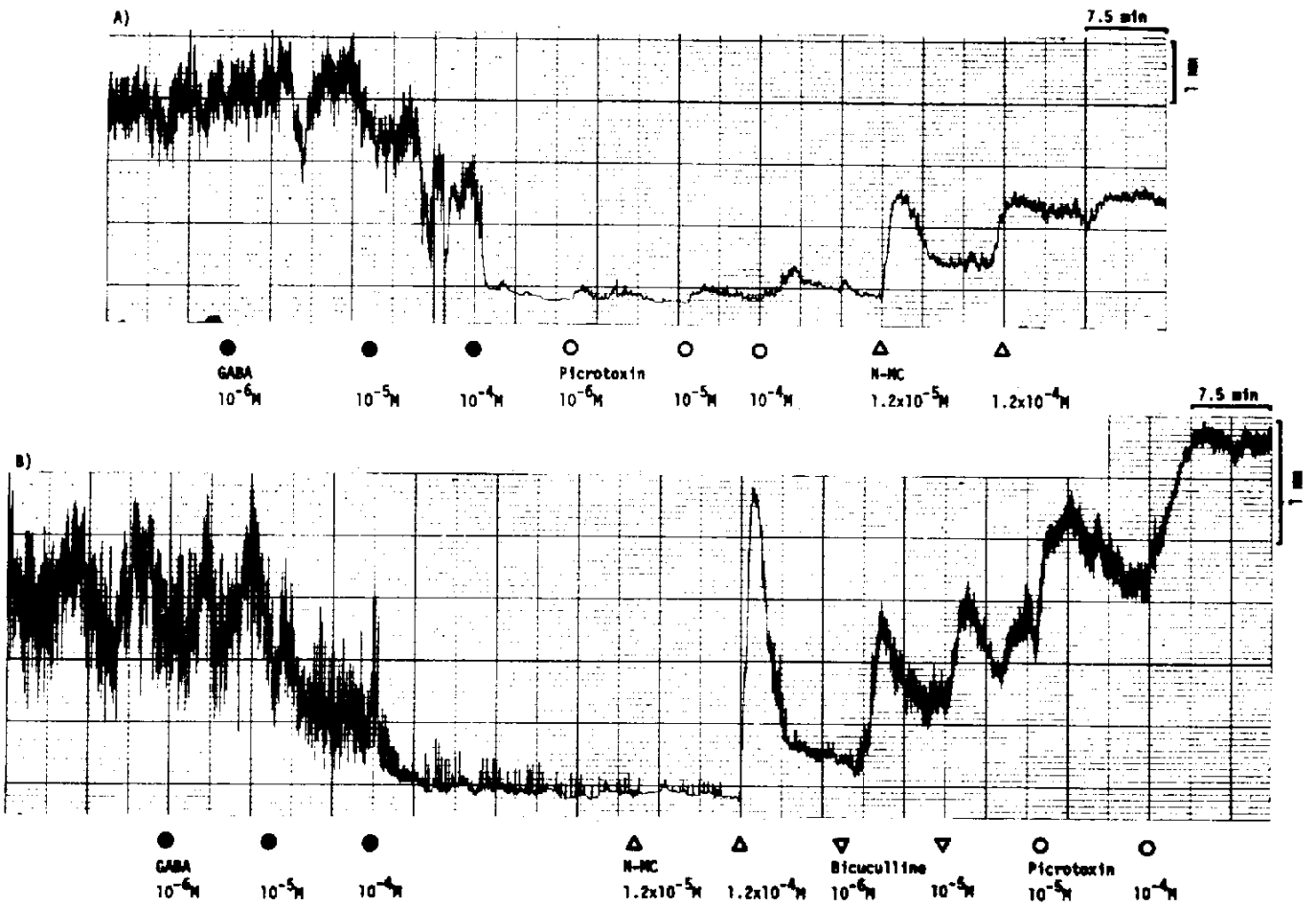

Fig. 1. Effects of GABA and its antagonists on the motility of A. cantonensis. Drugs were cumulatively given: and $\gamma$-aminobutyric acid (GABA, $\left.10^{-6}-10^{-1} \mathrm{M}\right)$, picrotoxin $\left(10^{-6}\right.$ $\left.10^{-4} \mathrm{M}\right)$, and $\mathrm{N}$-methylcytisine ( $\left.\mathrm{N}-\mathrm{MC}, 1.2 \times 10^{-5}-1.2 \times 10^{-4} \mathrm{M}\right)$ in $\left.\mathrm{A}\right)$ and $\mathrm{GABA}\left(10^{-6}\right.$ $\left.10^{-4} \mathrm{M}\right)$. N-MC $\left(1.2 \times 10^{-5}-1.2 \times 10^{-4} \mathrm{M}\right)$, bicuculline $\left(10^{-6}-10^{-5} \mathrm{M}\right)$, and picrotoxin $\left(10^{-5}-10^{-4} \mathrm{M}\right)$ in $\left.B\right)$ were successively given. 
GABA $\left(10^{-4} \mathrm{M}\right)$ were slightly antagonized by the single addition of picrotoxin $\left(10^{-6}\right.$ $\left.10^{-4} \mathrm{M}\right)$ or $\mathrm{N}-\mathrm{MC}\left(1.2 \times 10^{-5}-1.2 \times 10^{-4} \mathrm{M}\right)$. and they were remarkably antagonized by the combined addition of $\mathrm{N}-\mathrm{MC}\left(1.2 \times 10^{-4} \mathrm{M}\right)$. bicuculline $\left(10^{-6}-10^{-5} \mathrm{M}\right)$ and picrotoxin $\left(10^{-5}-10^{-4} \mathrm{M}\right)$ (Fig. 1). The eserine $\left(10^{-7}\right.$. $\left.10^{-5} \mathrm{M}\right)$-induced contraction was inhibited by the pretreatment with GABA $\left(10^{-4} \mathrm{M}\right)$. but not by picrotoxin $\left(10^{-5} \mathrm{M}\right)$ (Fig. 2).

The paralysis induced by Av-Bia (3.6x $\left.10^{-15} \mathrm{M}\right)$ was not reversed by the combined addition of $\mathrm{N}-\mathrm{MC}\left(1.2 \times 10^{-5} \quad \mathrm{M}\right)$ with dibenamine $\left(10^{-5}-10^{-4} \mathrm{M}\right)$, but reversed by N-MC $\left(1.2 \times 10^{-7} M\right)$ with picrotoxin $\left(10^{-5}\right.$ $M)$ and also by eserine $\left(10^{-5} \mathrm{M}\right)$ with picrotoxin $\left(10^{-4} \mathrm{M}\right)$ (Fig. 3A).

Effects of adrenergic agents on the motility of $A$. cantonensis: Paralysis was caused by adrenaline $\left(2.7 \times 10^{-5}-2.7 \times 10^{-4}\right.$
M). noradrenaline $\left(3 \times 10^{-6}-6 \times 10^{-5} \mathrm{M}\right)$, phenylephrine $\left(10^{-6}-3 \times 10^{-5} \mathrm{M}\right)$, methoxamine $\left(4 \times 10^{-5}-1.2 \times 10^{-4} \mathrm{M}\right)$, and clonidine $\left(2.8 \times 10^{-6}-1.4 \times 10^{-5} \mathrm{M}\right)$, but not by isoproterenol $\left(4.7 \times 10^{-7}-4.7 \times 10^{-5} \mathrm{M}\right)$ (Figs 4-7).

Dibenamine $\left(10^{-5}-10^{-4} \mathrm{M}\right)$ stimulated tonically and phasically the motility and also the preparations paralyzed by phenylephrine $\left(3 \times 10^{-5} \mathrm{M}\right)$, methoxamine $\left(8 \times 10^{-5} \mathrm{M}\right)$, and clonidine $\left(7 \times 10^{-6} \mathrm{M}\right)$ as respectively shown in Figs. 4C, 5B, 6. Phentolamine $\left(3.6 \times 10^{-6}\right.$ $\left.10^{-5} \mathrm{M}\right)$ antagonized the preparation paralyzed by phenylephrine $\left(3 \times 10^{-5} \mathrm{M}\right)$ (Fig. 5A). On the other hand, propranolol $\left(10^{-7}-10^{-5} \mathrm{M}\right)$ showed little effect on the motility and also on the paralysis induced by adrenaline $\left(2.7 \times 10^{-4} \mathrm{M}\right)$ and phenylephrine $\left(3 \times 10^{-5} \mathrm{M}\right)$ (Figs. 4A, B, 5A).

Paralysis elicited by noradrenaline $\left(6 \times 10^{-5}\right.$
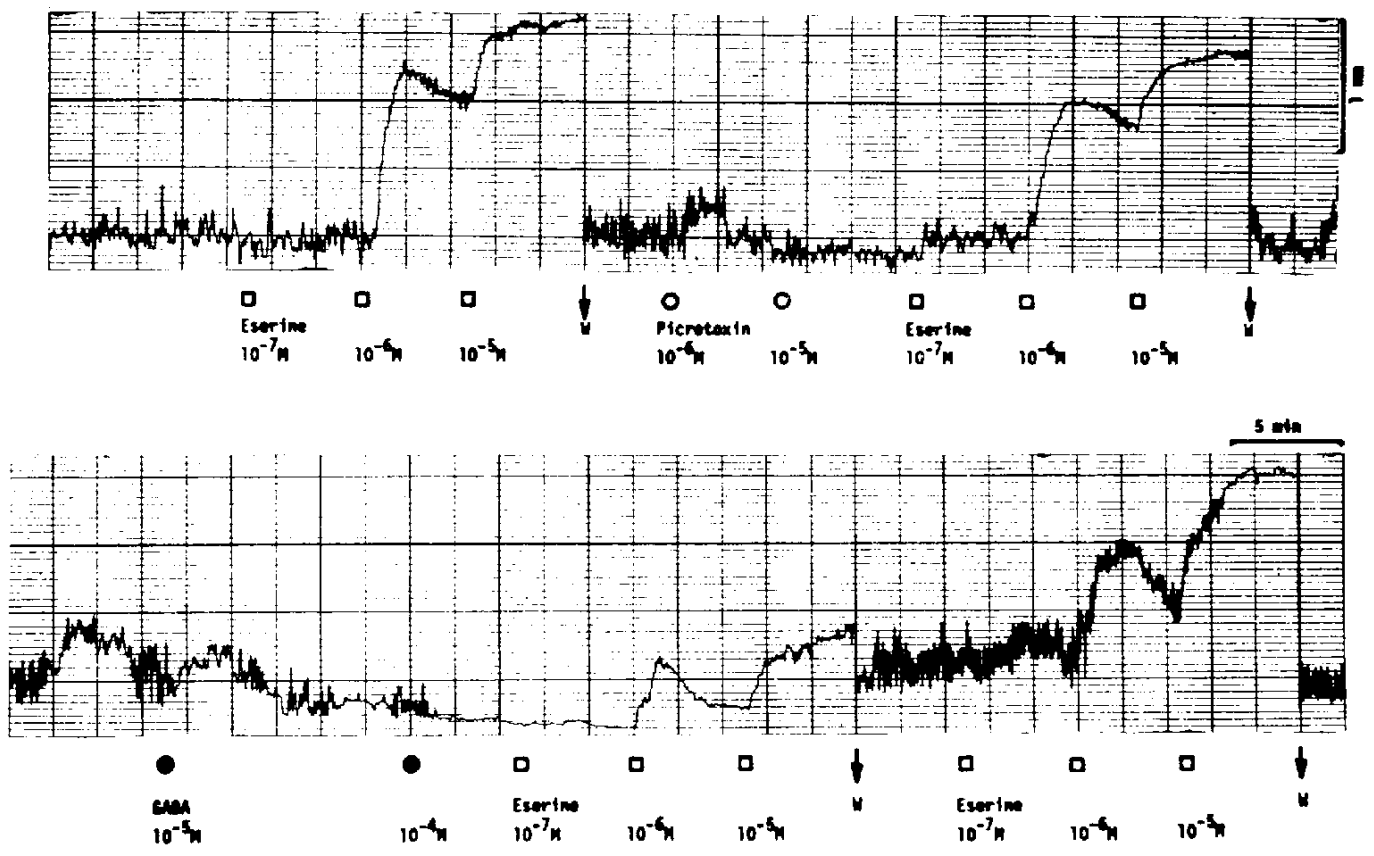

Fig. 2. Effects of picrotoxin and GABA on the eserine-induced contraction in A. cantonensis. Upper and lower traces are continuous. Drugs were cumulatively given, and eserine $\left(10^{-7}-10^{-5} \mathrm{M}\right)$ was given with or without treatment by picrotoxin $\left(10^{-6}-10^{-5} \mathrm{M}\right)$ or $\gamma$-aminobutyric acid (GABA, $10^{-5}-10^{-i} \mathrm{M}$ ). At the point $W$, the preparation was washed by Trrode's solution. 

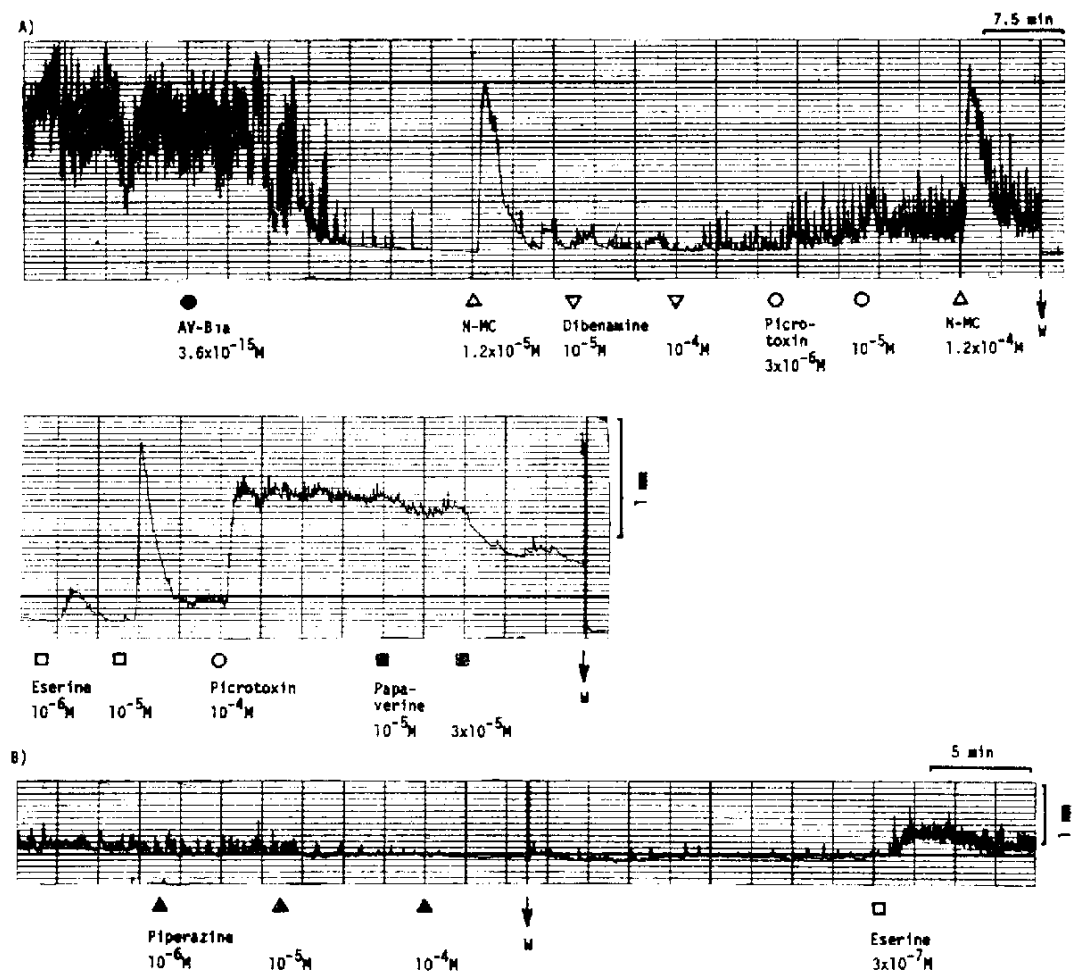

Fig. 3. Effects of avermectin Bla (Av-Bia), piperazine, and other agents on the motility of A. cantonensis. Some drugs were cumulatively given. A): Upper and middie traces aro continuous. Av-Bra $\left(3.6 \times 10^{-15} \mathrm{M}\right)$. N-methylcytisine (N-MC, $\left.1.2 \times 10^{-5} \mathrm{M}\right)$, dibenamine $\left(10^{-5}-10^{-4} \mathrm{M}\right)$, picrotoxin $\left(3 \times 10^{-6}-10^{-5} \mathrm{M}\right)$, and $\mathrm{N}-\mathrm{MC}\left(1.2 \times 10^{-4} \mathrm{M}\right)$ in the upper trace and eserine $\left(10^{-6}-10^{-5} \mathrm{M}\right)$, picrotoxin $\left(10^{-4} \mathrm{M}\right)$, and papaverine $\left(10^{-5}-3 \times 10^{-5} \mathrm{M}\right)$ in tho middle trace were successively giver. B): Effects of piperazine $\left(10^{6}-10^{-4} \mathrm{M}\right)$ and eserine $\left(3 \times 10^{-7} \mathrm{M}\right)$ were examined. At the point $\mathrm{W}$. preparations were washed by Tyrode's solution.

M) or clonidine $\left(7 \times 10^{-6} \mathrm{M}\right)$ was antagonized and contraction was caused by spasmogens such as $N-M C\left(1.2 \times 10^{-4} \mathrm{M}\right)$ and eserine $\left(10^{-6} \mathrm{M}\right)$ (Fig. 7 ).

Effects of 5-HT on the motility of $A$. cantonensis: $5-\mathrm{H}^{\top}\left(10^{-6}-10^{-4} \mathrm{M}\right)$ caused paralysis in many preparations $(70 \%, n=10)$. but caused contraction in other preparations (30\%, $n=10$ ) (Figs. 8, 9A, B).

The paralysis induced by 5-HT was antagonized by the addition of dibenamine $\left(10^{-5}-3 \times 10^{-5} \mathrm{M}\right)$ or phentolamine $\left(10^{-5} \mathrm{M}\right)$ (Figs. 8B, C). The action of eserine $\left(10^{-7}-\right.$ $\left.10^{-5} \mathrm{M}\right)$ was inhibited in the paralyzed preparation by $5-H T\left(10^{-5}\right.$ or $\left.10^{-4} \mathrm{M}\right)$, while this inhibition was reversed by the treatment with dibenamine $\left(3 \times 10^{-5} \mathrm{M}\right)$ or phentolamine $\left(10^{-5} \mathrm{M}\right)$ (Fig. 8). On the other hand. the contraction induced by $5-\mathrm{HT}\left(10^{-5} \mathrm{M}\right)$ was further stimulated by $\mathrm{N}-\mathrm{MC}\left(1.2 \times 10^{-5}\right.$ $\left.1.2 \times 10^{-4} \mathrm{M}\right)$, but antagonized by strychnine $\left(3 \times 10^{-6} \mathrm{M}\right)$ (Fig. 9A, B).

Effects of papaverine on the motility of A. cantonensis: Papaverine $\left(10^{-5}-3 \times 10^{-5}\right.$ M) paralyzed the motility of $A$. cantonensis. and it also blocked the eserine $\left(10^{-7}-10^{-6}\right.$ M)-induced contraction (Fig. 9C). This alkaloid $\left(10^{-5}-3 \times 10^{-5} \mathrm{M}\right)$ also paralyzed the reversed preparation by the combined addition of eserine $\left(10^{-5} \mathrm{M}\right)$ with picrotoxin 

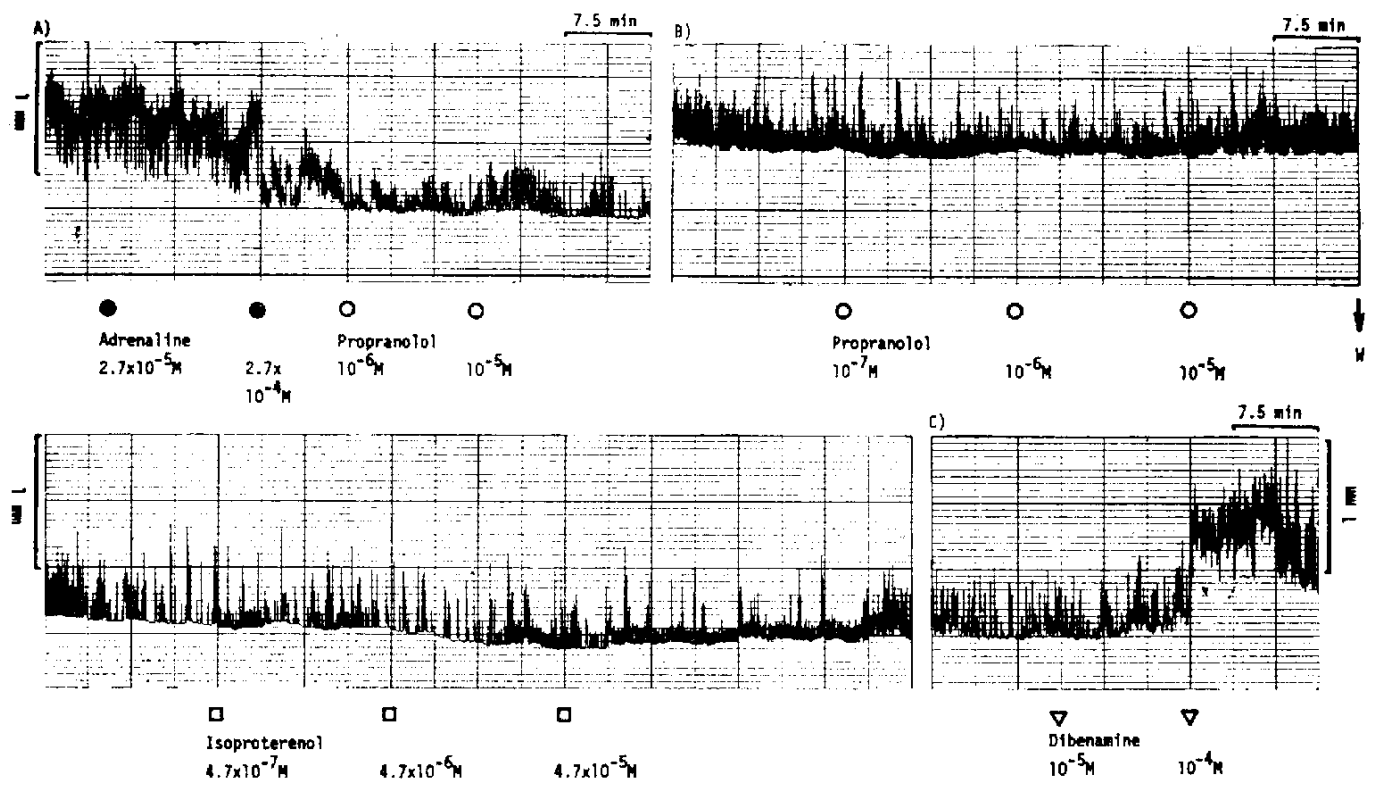

Fig. 4. Effects of various adrenergic agonists and antagonists on the motility of $A$. cantonensis. Upper and middle traces of $B$ ) are continuous. Drugs were cumulatively given. Effects of adrenaline $\left(2.7 \times 10^{-5}-2.7 \times 10^{-4} \mathrm{M}\right)$, propranolol $\left(10^{-7}-10^{-5} \mathrm{M}\right)$, isoproterenol $\left(4.7 \times 10^{-7}-4.7 \times 10^{-5} \mathrm{M}\right)$, and dibenamine $\left(10^{-5}-10^{-4} \mathrm{M}\right)$ were examined. Adrenaline and propranolol in A) were successively given. At the point $W$, the preparation was washed by Tyrode's solution.

$\left(10^{-4} \mathrm{M}\right)$ in $A$. cantonensis which had been treated with Av-Bia $\left(3.6 \times 10^{-15} \mathrm{M}\right)$ (Fig. 3A).

Effects of other possible neurotransmitters on the motility of $A$. cantonensis: Glutamate $\left(10^{-5}-10^{-4} \mathrm{M}\right)$, glycine $\left(10^{-5}-10^{-4} \mathrm{M}\right)$, aspartic acid $\left(10^{-5}-10^{-4} \mathrm{M}\right)$, taurine $\left(10^{-5}\right.$ $\left.10^{-4} \mathrm{M}\right)$, and substance $P\left(10^{-5}-5 \times 10^{-5} \mathrm{~g} /\right.$ $\mathrm{ml}$ ) showed little effect on the motility of A. cantonensis.

\section{DISCUSSION}

In contrast to $A$. suum, a traditional experimental model of parasitic nematodes. there has been no report regarding the neuropharmacology of $A$. cantonensis, a new model introduced by us for pharmacological studies. Up to this time, no data have been reported concerning neuropharmacological responses, the presence of neurotransmitters and enzymes responsible for synthesizing or inactivating these transmitters in this worm.

In the present study, inhibitory mechanisms including the GABA mechanism which is similar to that reported in A. suum $(2,4,5,11)$ and the $\alpha$-adrenergic mechanism were suggested to be in A. cantonensis.

Similar to the results on Ascaris muscle preparations $(2,4,5,11)$, the motility of a whole worm preparation of $A$. cantonensis was paralyzed by GABA, piperazine, and $A v-B i a$. The sensitivity of $A$. cantonensis to $A v$-Bia was remarkably better than that of the Ascaris muscle preparations, while the sensitivity to GABA and piperazine was not different $(2,4,5,11,12)$. The paralytic action of GABA was antagonized by GABA antagonists such as bicuculline and picrotoxin (13) with $\mathrm{N}-\mathrm{MC}$, a stimulant of the release of $A C h$ in $A$. cantonensis (14). The paralytic action of Av-Bia was also antagonized by GABA antagonists with N-MC or eserine. 

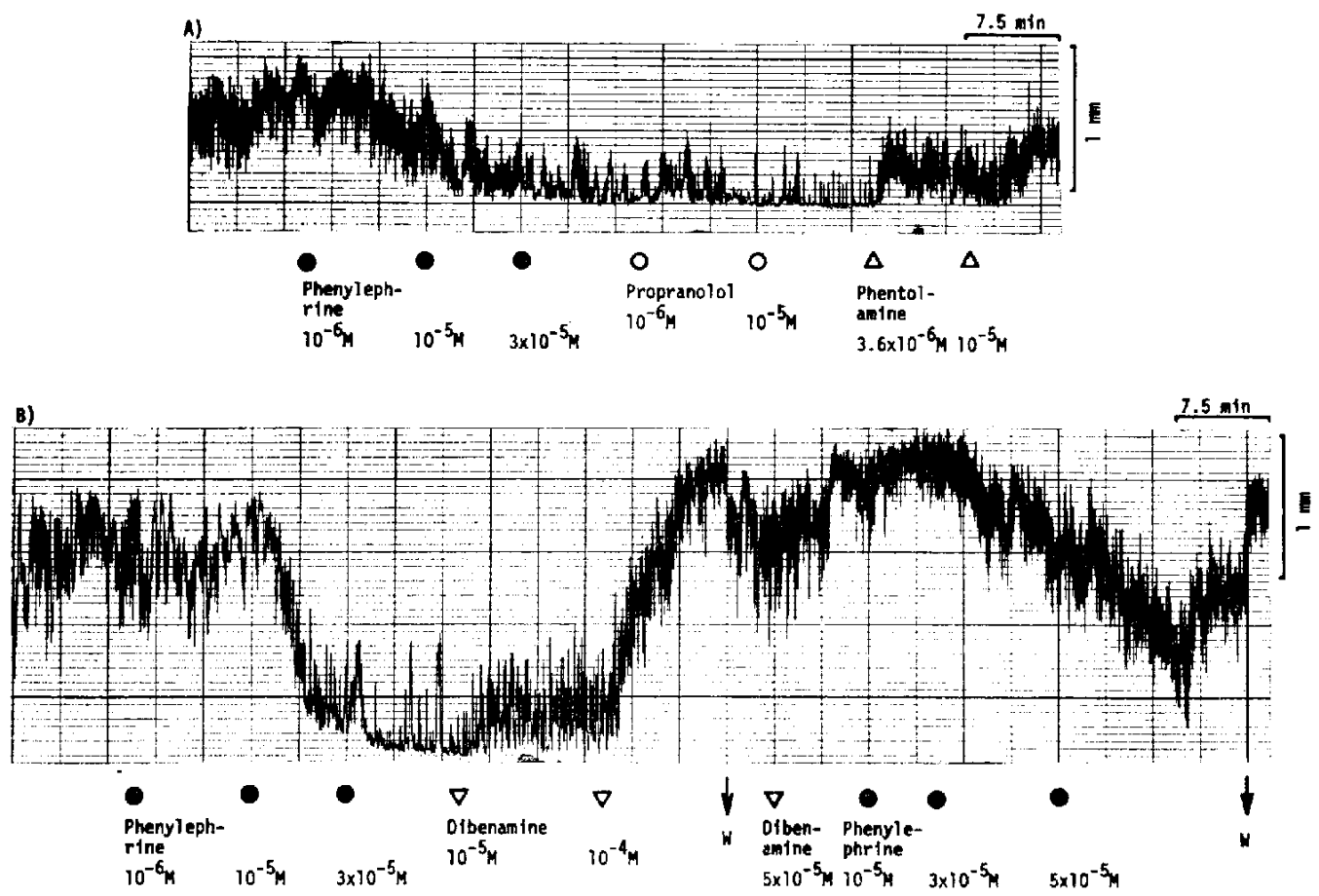

Fig. 5. Effects of phenylephrine and its antagonists on the motility of A. cantonensis. Drugs were given cumulatively, and agonists and antagonists were successively given. A) Effects of propranolol $\left(10^{-6}-10^{-5} \mathrm{M}\right)$ and phentolamine $\left(3.6 \times 10^{-6}-10^{-5} \mathrm{M}\right)$ on the preparation paralyzed with phenylephrine $\left(10^{-6}-3 \times 10^{-5} \mathrm{M}\right)$ were examined. B): Dibenamine $\left(10^{-5}-10^{-4}\right.$ or $\left.5 \times 10^{-5} \mathrm{M}\right)$ was given before or after the treatment with phenylephrine $\left(10^{-6}-3 \times 10^{-5}\right.$ or $\left.10^{-5}-5 \times 10^{-5} \mathrm{M}\right)$. At the point $\mathrm{W}$. the preparation was washed by Tyrode's solution.

but not by dibenamine with $\mathrm{N}-\mathrm{MC}$. Thus, it is suggested that GABA has a role as an inhibitory neurotransmitter in $A$. cantonensis as welt as in $A$. suum $(2,4,5,11)$.

It was reported that adrenergic agents such as adrenaline showed little effect on Ascaris muscle preparations (1). On the other hand, the motility of $A$. cantonensis was paralyzed by $\alpha$-adrenergic agonists such as adrenaline, noradrenaline, phenylephrine, methoxamine, and clonidine, but not by $\beta$ adrenergic agonists such as isoproterenol. The paralysis induced by $\alpha$-adrenergic agonists was blocked by $\alpha$-adrenergic antagonists such as dibenamine and phentolamine, but not by $\beta$-adrenergic antagonists such as propranolol. In addition, $\alpha$-adrenergic agonists as well as GABA were affected antagonistically with excitatory cholinergic agents such as eserine and N-MC. These results suggest a possible involvement of an $\alpha$-adrenergic mechanism as an inhibitory one in A. cantonensis. Since dibenamine stimulated remarkably the motility with or without the treatment by $\alpha$-adrenergic agonists, the inhibitory role of the $\alpha$-adrenergic mechanism appears to be rather significant. However. there are probably other reasons for the stimulating effect of dibenamine. For example. this effect appears to be reasonably supported through postulating that dibenamine also has a stimulant action on the excitatory cholinergic mechanism in this worm.

From the results on cholinergic agents (7). 

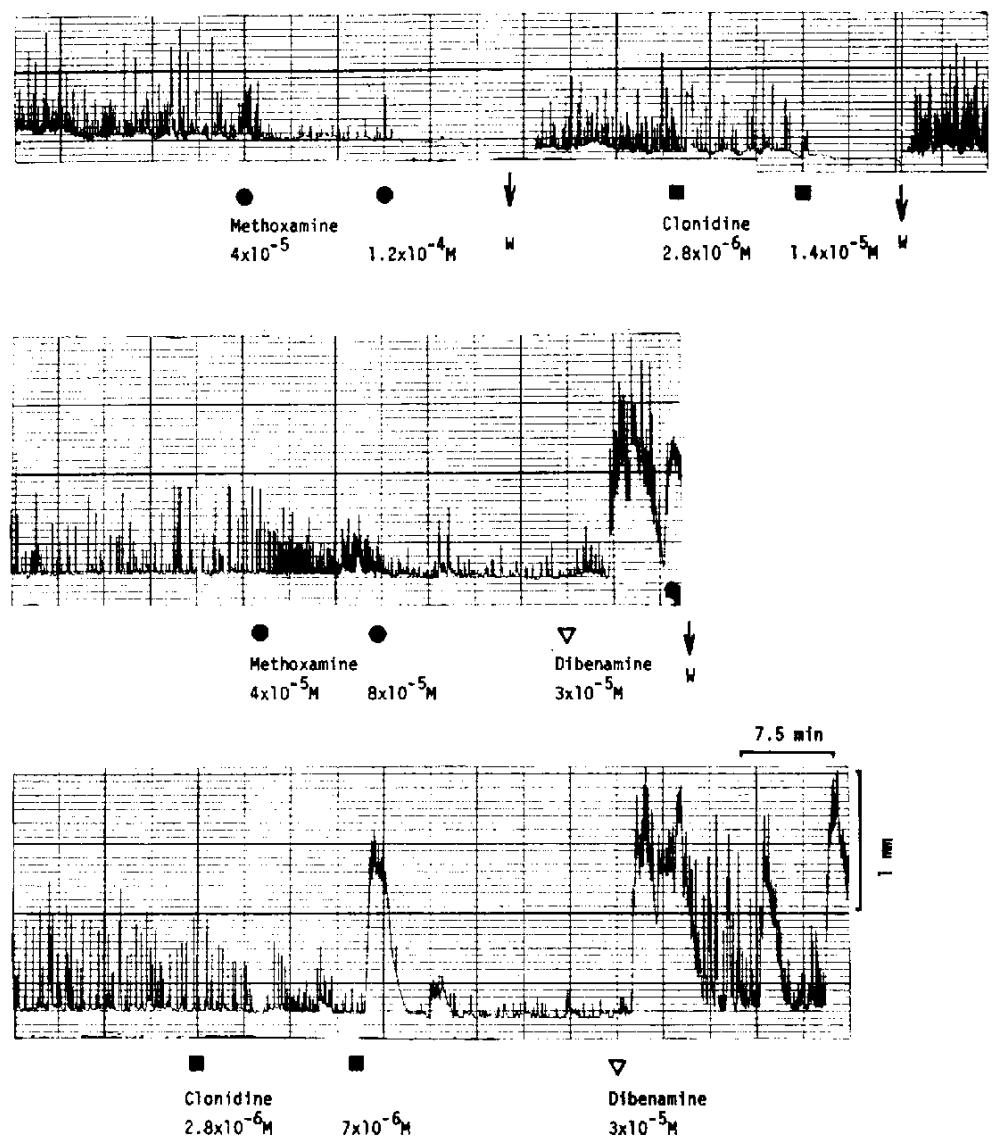

Fig. 6. Effects of methoxamine and clonidine and their antagonist, dibenamine, on the motility of $A$. cantonensis. All traces are continuous. Upper trace: Effects of methoxamine $\left(4 \times 10^{-5}-1.2 \times 10^{-4} \mathrm{M}\right)$ and clonidine $\left(2.8 \times 10^{-6}-1.4 \times 10^{-5} \mathrm{M}\right)$ were examined. Middle and lower traces: Dibenamine $\left(3 \times 10^{-5} \mathrm{M}\right)$ was given after the treatment with methoxamine $\left(4 \times 10^{-5}-8 \times 10^{-5} \mathrm{M}\right)$ or clonidine $\left(2.8 \times 10^{-6}-7 \times 10^{-6} \mathrm{M}\right)$. At the point W, the preparation was washed by Tyrode's solution.

the muscle of $A$. cantonensis is suggested to be similar to the skeletal muscle rather than the ileal smooth muscle. However, the muscle is suggested to have some properties similar to the smooth muscle from the results on $\alpha$-adrenergic agents and papaverine. It has been reported that 5 - HT acts spastically or paralytically on the motility of the intestinal smooth muscle in mammals (15). This compound also acted spastically or paralytically on the motility of $A$. cantonensis. From the relationship between $5-\mathrm{HT}$ and other agents such as $\alpha$-adrenergic antago- nists, eserine and strychnine, it is suggested that 5-HT probably acts through increasing the release of neurotransmitters in this worm.

The motility of $A$. cantonensis was affected by many important neuropharmacological agents such as nicotinic cholinergic agonists, GABA, $\alpha$-adrenergic agonists and 5-HT, and their antagonists. In addition, atropine stimulated the motility of this worm (7). These results suggest that the responses to drugs in A. cantonensis are partially similar to those in the brain of mammals. Since the larvae of this worm migrate to the central nervous system 

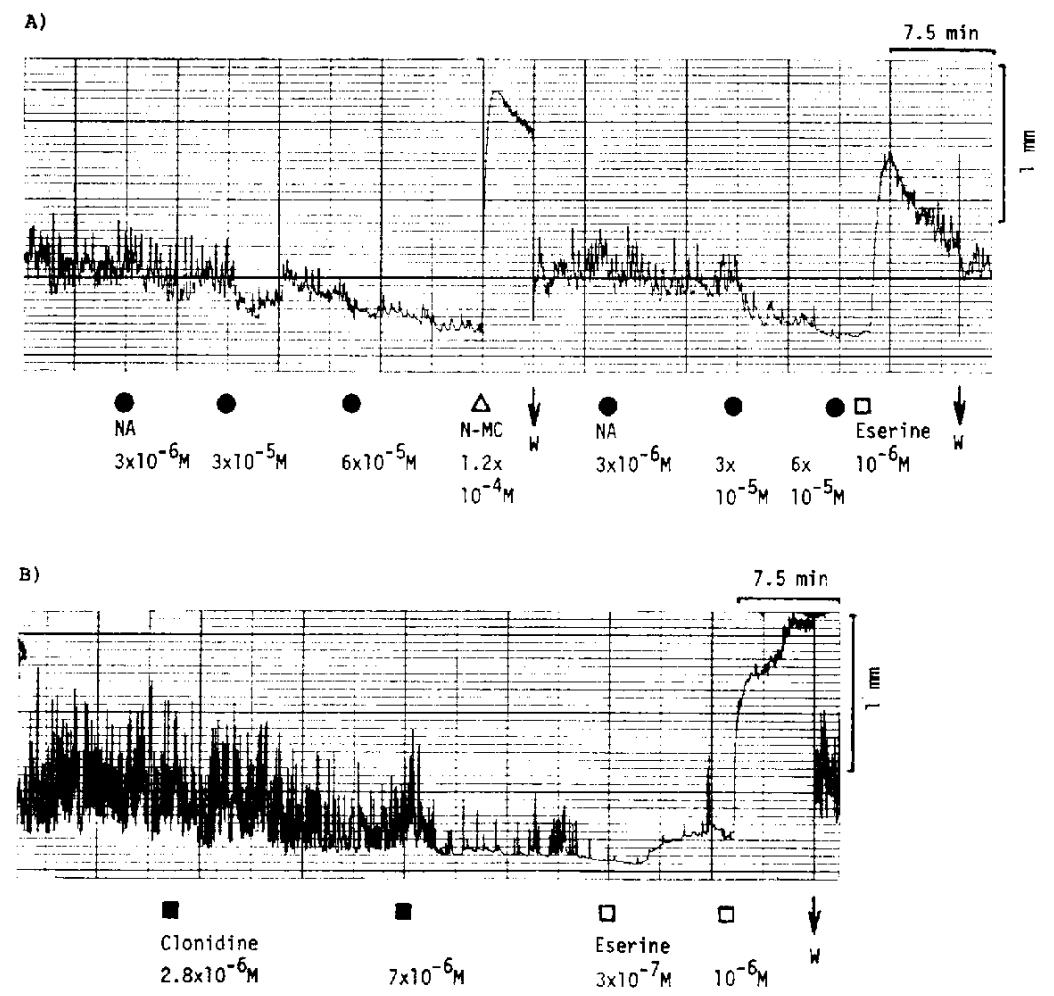

Fig. 7. Effects of $N$-methylcytisine (N-MC) and eserine on the preparation paralyzed with roradrenaline (NA) or clonidine in $A$. cantonensis. Some drugs were given cumulatively. A): N-MC $\left(1.2 \times 10^{-4} \mathrm{M}\right)$ or eserine $\left(10^{-6} \mathrm{M}\right)$ was given after the treatment with NA $\left.\left(3 \times 10^{-6}-6 \times 10^{-5} \mathrm{M}\right), \quad B\right)$ : Eserine $\left(3 \times 10^{-7}-10^{-6} \mathrm{M}\right)$ was given after the treatment with clonidine $\left(2.8 \times 10^{-6}-7 \times 10^{-6} \mathrm{M}\right)$. At the point $W$. preparations were washed by Tyrode's solution.

of mammals and stay there to develop to young adult worms for about 20 days in their life cycle (16), the above-mentioned suggestion is rather likely. In the present study, however, other tentative neurotransmitters in the central nervous system such as glycine, glutamate, aspartic acid, taurine, and substance $P$ showed little effect on the motility of $A$. cantonensis.

Thus, from these findings on the neuropharmacological properties of $A$. cantonensis, it is suggested that this worm is useful as an excellent model of nematodes for the investigation of anthelminthics. It seems also to be worthwhile studying the effects of various drugs on this worm from other viewpoints such as comparative pharma- cology $(8,14)$. Comparison to neuromuscular junctions both in vertebrates including mammals and in invertebrates is probably interesting. In addition, this worm may also have use as one of the screening models for drugs affecting the central nervous system in mammals. Though we reported that Av-Bia paralyzed the motility of A. cantonensis through activating the GABA mechanism (17), it is also reported that this drug affects the GABA mechanism in the brain of mammals $(18,19)$ and influences the actions of drugs such as diazepam $(20,21)$. $\alpha$-Adrenergic agonists such as clonidine and methoxamine paralyzed the motility of $A$. cantonensis, while there is interest in these drugs as cardiovascular depressants which are as- 

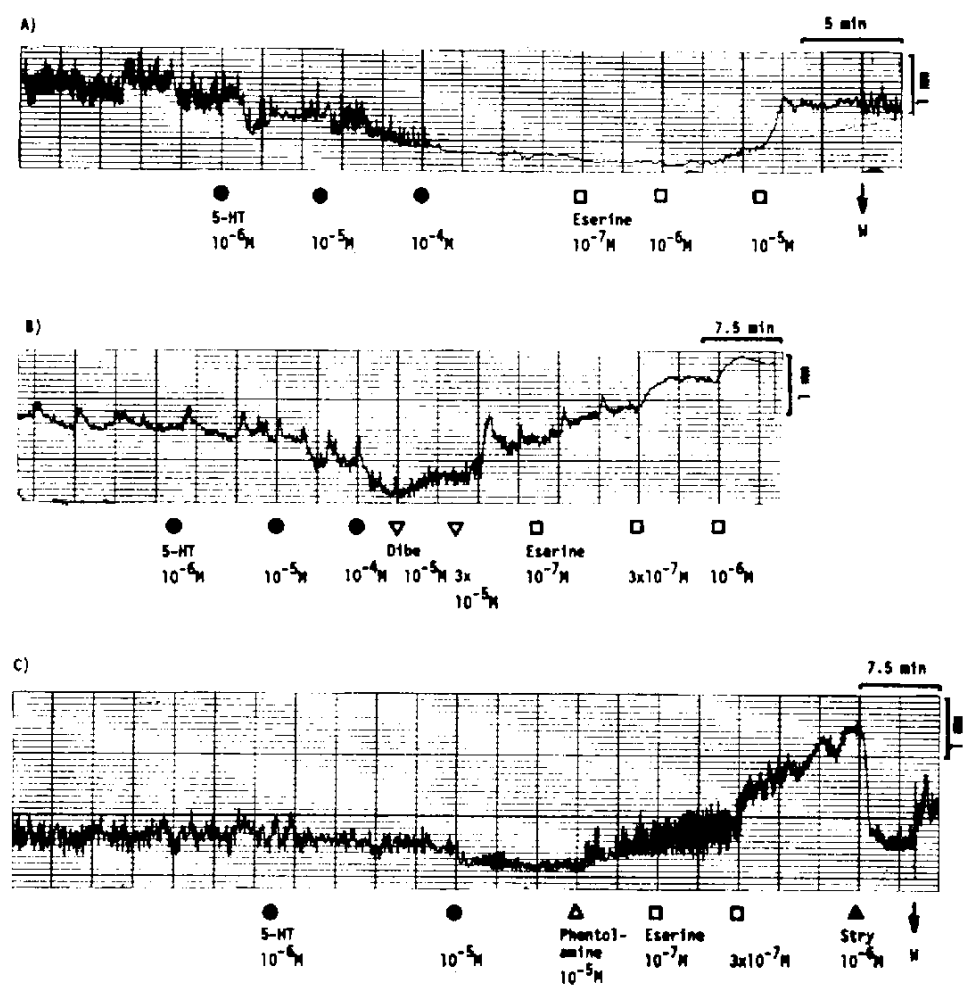

Fig. 8. Effects of 5-hydroxytryptamine $(5-\mathrm{HT})$ and other agents on the motility of A. cantonensis. Drugs were cumulatively given. A): Eserine $\left(10^{-7}-10^{-5} \mathrm{M}\right)$ was given to the preparation paralyzed by $5-H T\left(10^{-6}-10^{-4} \mathrm{M}\right)$. B) and $\left.\mathrm{C}\right)$ : Eserine $\left(10^{-7}-10^{-6}\right.$ or $\left.3 \times 10^{-7} \mathrm{M}\right)$ was given to the preparations paralyzed by $5-\mathrm{HT}\left(10^{-6}-10^{-4} \mathrm{M}\right)$ after the treatment with dibenamine (Dibe, $10^{-5}-3 \times 10^{-5} \mathrm{M}$ ) or phentolamine $\left(10^{-5} \mathrm{M}\right.$ ). At the point $W$, preparations were washed by Tyrode's solution.

sociated with central $\alpha$-adrenoceptors and presynaptic $\alpha$-adrenoceptors (22).

\section{REFERENCES}

1) Baldwin, E. and Moyle, V.: A contribution to physiology and pharmacology of Ascaris lumbricoides from the pig. Brit. J. Pharmacol. 4. 145-152 (1949)

2) Norton, S. and De Beer, E.J.: Investigations on the action of piperazine on Ascaris lumbricoides. Am. J. trop. Med. Hyg. 6, 898-905 (1957)

3) Natoff, I.L.: The pharmacology of the cholinoceptor in muscle preparations of Ascaris lumbricoides var. suum. Brit. J. Pharmacol. 37. 251-257 (1969)

4) Del Castilio, J. and Morales, T.: Electrophysiological experiments in Ascoris lumbricoides. In Experiments in Physiology and Biochemistry. Edited by Kerkut, G.A., Vol. 2, p. 209-273, Academic Press. New York (1969)
5) Hayashi, E., Haruno, A., Shimizu, T. and Terada, $M$.: The specificity of pharmacological responses in Ascaris muscle. Folia pharmacol. japon. 76, 15-24 (1980) (Abs. in English)

6) Terada, M., Sano, M., Ishii, A.l., Kino, H., Fukushima, $\mathrm{S}$. and Noro, T.: Studies on chemotherapy of parasitic helminths (Iil). Effects of tuberostemonine from Stemona japonica on the motility of parasitic helminths and isolated host tissues. Folia pharmacol. japon. 79, 93103 (1982) (Abs. in English)

7) Terada, M., Ishii, A.I., Kino, H. and Sano, M.: Studies on chemotherapy of parasitic helminths (VII). Effects of various cholinergic agents on the motility of Angiostrongylus cantonensis. Japan. J. Pharmacol. 32, 633-642 (1982)

8) Kuriyama, K., Yoneda, Y. and Muramatsu, M.: Comparative biology of chemical transmitters. Metabolism 14, 749-759 (1977)

9) Bradley, P.B. and Dhawan, B.N.: Drugs and Central Synaptic Transmission. The Macmillan 

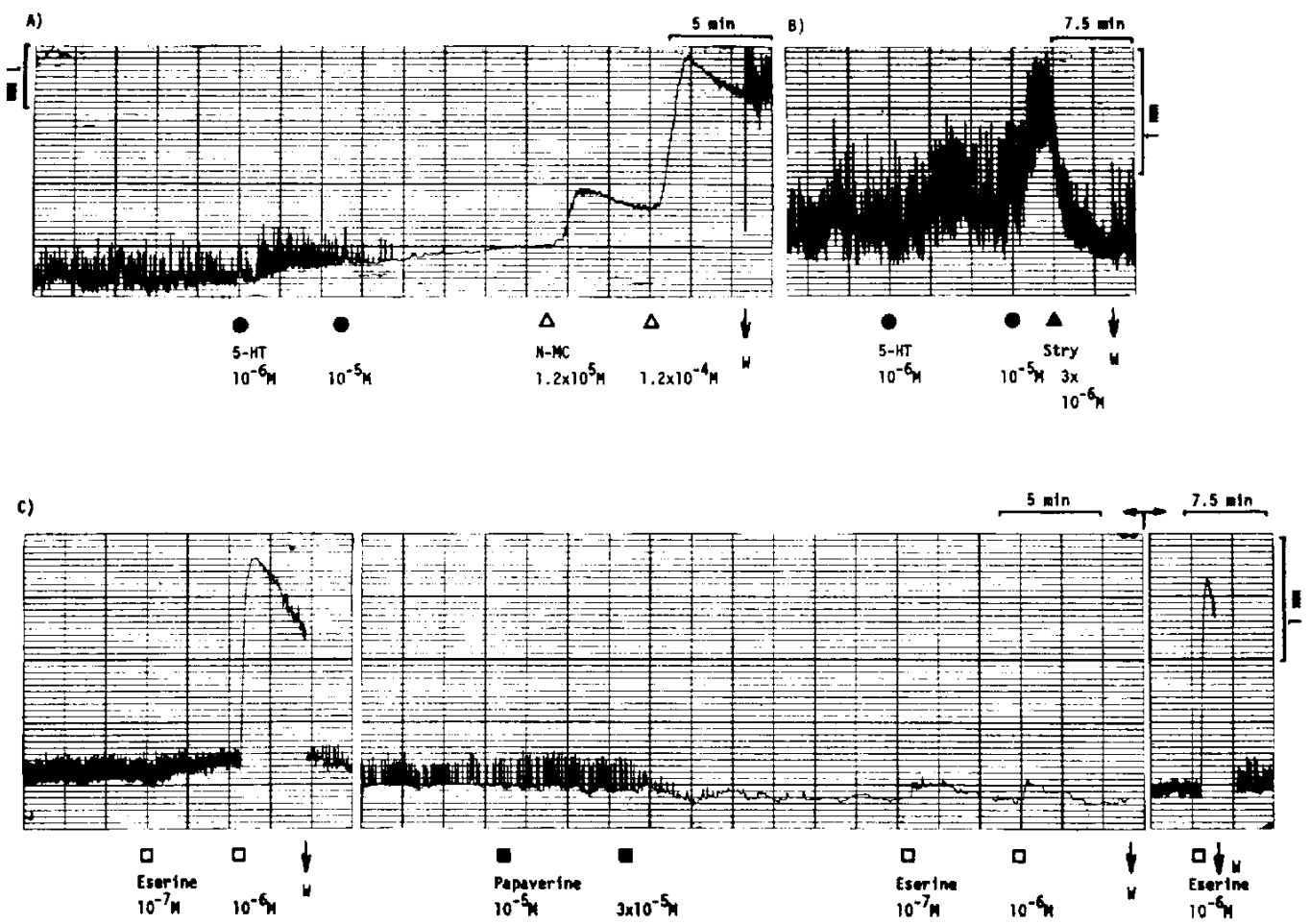

Fig. 9. Effects of 5-hydroxytryptamine (5-HT), papaverine, and other agents on the motility of A. cantonensis. Drugs were cumulatively given. A) and $B$ ): N-methylcytisine ( $N$ MC. $\left.1.2 \times 10^{-5}-1.2 \times 10^{-4} \mathrm{M}\right)$ or strychnine $\left(3 \times 10^{-6} \mathrm{M}\right)$ was given to the contracted preparation by $5-\mathrm{HT}\left(10^{-6}-10^{-5} \mathrm{M}\right)$. C) : Eserine $\left(10^{-7}-10^{6} \mathrm{M}\right)$ was given with or without the treatment with papaverine $\left(10^{-5}-3 \times 10^{-5} \mathrm{M}\right)$. At the point $W$. preparations were washed by Tyrode's solution.

Press Limited, London and Basingstke (1976)

10) Sano, M., Terada, M., Ishii, A.I., Kino, H. and Hayashi, M.: Studies on chemotherapy of parasitic helminths (1). On the in vitro methods and paralyzing effects of avermectin Bia on Angiostrongylus cantonensis. Japan. J. Parasitol. 30, 305-314 (1981)

11) Kass, I.S., Wang, C.C., Walrond, J.P. and Stretton, A.O.W.: Avermectin Bia a paralyzing anthelmintic that affects interneurons and inhibitory motorneurons in Ascaris. Proc. Natn. Acad. Sci. U.S.A. 77, 6211-6215 (1980)

12) Sano, M., Terada, M., Ishii, A.l. and Kino, H.: Effects of avermectin $\mathrm{B} 1 \mathrm{a}$ on the motility of various parasitic helminths. Experientia 37. 844-846 (1981)

13) Andrews, P.R. and Johnston, G.A.R.: GABA agonists and antagonists. Biochem. Pharmacol. 28, 2697-2702 (1979)

14) Terada, M., Sano, M., Ishii, A.l., Kino, H., Fukushima, S. and Noro, T.: Studies on chemo- therapy of parasitic helminths (IV). Effects of alkaloids from Sophora flavescens on the motility of parasitic helminths and isolated host tissues. Folia pharmacol. japon. 79, 105-111 (1982) (Abs. in English)

15) Bando, T., Takagi, K. and Ebashi, S.: Physiology and Pharmacology of Smooth Muscles. Nankodo (1974)

16) Mackerras, M.J. and Sandars, D.F.: The life history of the rat lung-worm. Angiostrongylus cantonensis (Chen) (Nematoda: Metastrongylidae). Aus. J. Zool. 3, 1-21 (1955)

17) Sano, M., Terada, M., Ishii, A.l., Kino, H. and Hayashi, M.: Studies on chemotherapy of parasitic helminths (9). Neuropharmacological mechanism of paralyzing action of avermectin in Angiostrongylus cantonensis. 8th intern. Congr. Pharmacol. Tokyo, Abstracts p. 443 (1981)

18) Pong, S.-S. and Wang, C.C.: The specificity of high-affinity binding of avermectin Bia to 
mammalian brain. Neuropharmacology 19, 311$317(1980)$

19) Pong, S.-S., Wang, C.C. and Fritz, L.C.: Studies on the mechanism of action of avermectin Bla: stimulations of release of $\gamma$-aminobutyric acid from brain synaptosomes. I. Neurochem. 34. $351-358(1980)$

20) Williams, M. and Yarbrough, G.G.: Enhancement of in vitro binding and some of the pharmacological properties of diazepam by a novel anthelmintic agent, avermectin Bia.
Europ. J. Pharmacol. 56, 273-276 (1979)

21) Paul, S.M., Skolnick, P. and Zatz, M.: Avermectin Bla: an irreversible activator of the $\gamma$-amiriobutyric acid-benzodiazepine-chlorideionophore receptor complex. Biochem. biophys. Res. Commun. 96, 632-638 (1980)

22) Kobinger, $W$.: The role of $\alpha$-adrenoceptors in central nervous and peripheral cardiovascular regulation. Japan. J. Pharmacol. 31, Supp. 13P-20P (1981) 